\title{
Community structure and trophic role of ciliates and heterotrophic nanoflagellates in Rhone River diluted mesoscale structures (NW Mediterranean Sea)
}

\author{
Urania Christaki ${ }^{1, *}$, Claude Courties ${ }^{2}$, Fabien Joux ${ }^{3}$, Wade H. Jeffrey ${ }^{4}$, \\ Jacques Neveux ${ }^{3}$, Jean-Jacques Naudin ${ }^{3}$ \\ ${ }^{1}$ Univ Lille Nord de France, ULCO, LOG, CNRS, UMR 8187, 32 Avenue Foch, 62930 Wimereux, France \\ ${ }^{2}$ UMPC Univ Paris 06, FRE 3247, MBCE, CNRS, Observatoire Océanologique, 66651 Banyuls-sur-Mer, France \\ ${ }^{3}$ UMPC Univ Paris 06, FRE 3247, MBCE, LOBB, CNRS, UMR 7621, Observatoire Océanologique, 66651 Banyuls-sur-Mer, France \\ ${ }^{4}$ Center for Environmental Diagnostics and Bioremediation, 11000 University Parkway, University of West Florida, Pensacola, \\ Florida 32514, USA
}

\begin{abstract}
Studies of the Rhone River plume, and in particular its diluted mesoscale structures, have shown over recent years that low salinity water (LSW) is characterised by both high primary and high secondary productivity. Here we compare the structure and grazing activity of the hetorotrophic community (nanoflagellates, ciliates) in the LSW and the surrounding marine water (MW) of the northwestern Mediterranean Sea. Furthermore, we report on the temporal variability of these characteristics all along a Lagrangian track in the LSW. In May 2006, salinity of the LSW ranged from 31.41 to 38.25 down to a depth of $35 \mathrm{~m}$, and surface chlorophyll a concentration reached $15.5 \mathrm{\mu g} \mathrm{l}^{-1}$. The ciliate community structure was similar in both the LSW and the MW, characterised by the dominance of the mixotrophic ciliates Laboea strobila and Myrionecta rubra. The ciliate biomass was approximately 6 times greater in the LSW, compared to the MW. This difference was due to the mixotrophic ciliates, which were about 4 - to 5 -fold more important in terms of abundance and biomass in the LSW, while heterotrophic ciliates only increased by a maximum of 2 -fold. M. rubra was the most abundant species reaching 4600 cells l$^{-1}$, while L. strobila was dominant in terms of biomass, accounting for $47 \%$ of total biomass in the LSW. Ciliates, in particular mixotrophs, were very active in the LSW where they grazed on phytoplankton at rates near their maximum clearance capacities. Mixotrophic and heterotrophic ciliates in LSW consumed about 50 and $10 \%$ of the nanophytoplankton stock per day, respectively. The mixotrophic ciliate $L$. strobila was found to be an efficient grazer of nanophytoplankton. In contrast to the ciliates, the biomass of heterotrophic nanoflagellates was similar in both the LSW and the MW; thus, we suggest that the transfer of bacterial biomass in the LSW towards higher trophic levels was moderate.
\end{abstract}

KEY WORDS: Bacterivory $\cdot$ Grazing $\cdot$ Mixotroph $\cdot$ Laboea strobila $\cdot$ Picoeucaryotes $\cdot$ Rhone River plume

\section{INTRODUCTION}

As the main river source flowing into the Mediterranean Sea, the Rhone River contributes an average of $\sim 1750 \mathrm{~m}^{3} \mathrm{~s}^{-1}$ of freshwater (Naudin et al. 1997). This represents a major nutrient source for the Gulf of Lions in the northwestern Mediterranean Sea, greatly influencing its productivity (Lefèvre et al. 1997). Despite the high nutrient concentrations available close to the mouth of the river, the rapid spread of the plume is not propitious to marine or freshwater phytoplankton development (Naudin et al. 2001). Depending on the 
density gradient induced by the river input, and the intensity of mixing processes, high bacterial production generally occurs within the first $10 \mathrm{~km}$ south-westward of the river mouth (Joux et al. 2005, Pujo-Pay et al. 2006). Farther offshore (10 to $20 \mathrm{~km}$ ), a zone of high primary productivity is often observed at salinity higher than 34 (Naudin et al. 2001). Recent studies have shown that, depending on seaward or landward prevailing wind conditions, diluted lenses of low-salinity water (LSW) may accumulate along the coast, detach from the plume, and then be transferred along the continental shelf (Diaz et al. 2008). As shown by satellite images (Bosc 2002), these diluted water masses may extend hundreds of kilometres southwestward and are associated with higher chlorophyll $a$ (chl a) concentrations than in the surrounding oligotrophic marine water (MW) of the Mediterranean Sea (Joux et al. 2009). These LSWs, isolated from their river origin, may be viewed as 'macrocosms' in which biological processes modify dissolved and particulate material during the offshore transfer.

Nanoflagellates are generally recognised as responsible for packaging bacterial biomass, enabling its transfer to higher trophic levels (e.g. Christaki et al. 2001). Together, nanoflagellates and ciliates play a key role in the transfer of bacterial and phytoplankton biomass to higher trophic levels through grazing. The quantity of carbon channelled to higher trophic levels is a consequence of both food web structure and the conversion efficiencies of the grazers. The role and importance of ciliates within these food webs also depends upon their trophic type. In general, planktonic ciliates can be thought of as being comprised of 2 groups: heterotrophs and mixotrophs (Stoecker et al. 1987, Laval-Peuto \& Rassoulzadegan 1988, Johnson \& Stoecker 2005). Mixotrophs exploit sequestered chloroplasts to supply a part of their nutritional requirements, a trophic mode that would, a priori, seem to be an adaptation to oligotrophic conditions (Dolan \& Pérez 2000). However, as a percentage of total ciliates, mixotrophs can vary between $<10 \%$ to almost $100 \%$ without a clear relationship to the trophic state of the system (e.g. Sime-Ngando et al. 1992, Verity \& Vernet 1992, Bernard \& Rassoulzadegan 1994).

Shelf-slope ecosystems occupy a relatively small proportion of the world ocean but yield the majority of its fish catch. Recent estimates indicate that on a global scale, the consumption of ciliates alone amounts to greater than one third of the C flux processed by zooplankton grazing on phytoplankton (e.g. Maar et al. 2002, Calbet \& Saiz 2005). In addition, ciliates are an excellent food source for copepods (Dutz \& Peters 2008) and may also be an important food source for organisms other than copepods. For example, a field study by Zhang et al. (2002) showed that peaks of cili- ates coincided not only with peaks of copepods but also with the post-larvae anchovy Engraulis japonicus in the coastal waters of the Yellow Sea. They suggested that large aloricate ciliates may be ingested by the first feeding anchovy larvae. In the northwestern Mediterranean Sea, high egg and larval abundance for anchovies were reported in hydrologic structures off the Catalan coast (Palomera 1992, Salat 1996). These zones of high abundance are associated with low salinity water (Tudela \& Palomera 1997) that could originate from the Rhone River (Sabatés et al. 2001). These authors have suggested that the larvae might benefit from remaining in water with high chl a concentration and microzooplankton abundance.

Here we describe the results derived from the field campaign, Biochemical processes in the Rhone freshwater influence (BIOPRHOFI), conducted from 14 to 28 May 2006 on board the French R/V 'Le Suroit' to characterise and compare the biogenic stocks and fluxes associated with both the LSW and the MW. A Langrangian sampling strategy was performed to document the hydrological conditions and biological processes as a function of time. Our objectives were to provide information on the nano- and microzooplankton in low salinity waters relative to MW, with emphasis on the heterotrophic nanoflagellates (HNF) and ciliates, and to examine their potential role in channelling carbon to the higher trophic levels. We hypothesized that the different water masses have different microbial food webs.

\section{MATERIALS AND METHODS}

Sampling site. The study area was located in the northwestern Mediterranean Sea off the mouth of the Rhone River. To localise the LSW with high chl a content, MODIS satellite images were received daily on board. Images indicated that the LSW were located 15 miles south of the river mouth at the start of the cruise and then moved 20 miles south-westward. (Fig. 1a). Consequently, 2 investigations were carried out, the first between $43^{\circ} 00^{\prime}$ to $43^{\circ} 03^{\prime} \mathrm{N}$ and $4^{\circ} 54^{\prime}$ to $4^{\circ} 57^{\prime} \mathrm{W}$, and the second between $42^{\circ} 53^{\prime}$ to $43^{\circ} 03^{\prime} \mathrm{N}$ and $4^{\circ} 28^{\prime}$ to $4^{\circ} 39^{\prime} \mathrm{W}$. Sampling campaigns lasted for 61 and $107 \mathrm{~h}$, respectively. The MW stations outside the LSW influence were also sampled at the start $\left(42^{\circ} 58^{\prime} \mathrm{N}\right.$ to $\left.5^{\circ} 30^{\prime} \mathrm{W}\right)$ and at the end of the cruise $\left(42^{\circ} 42^{\prime} \mathrm{N}\right.$ to $\left.4^{\circ} 37^{\prime} \mathrm{W}\right)$.

Sampling strategy. The Lagrangian sampling strategy was based on the deployment of a $10 \mathrm{~m}$ high Holey-sock buoy, drifting between 5 and $15 \mathrm{~m}$ depth. During each trajectory, hourly CTD profiles of temperature and conductivity were recorded with a SeaBird 9/11+ equipped with additional sensors for fluores- 

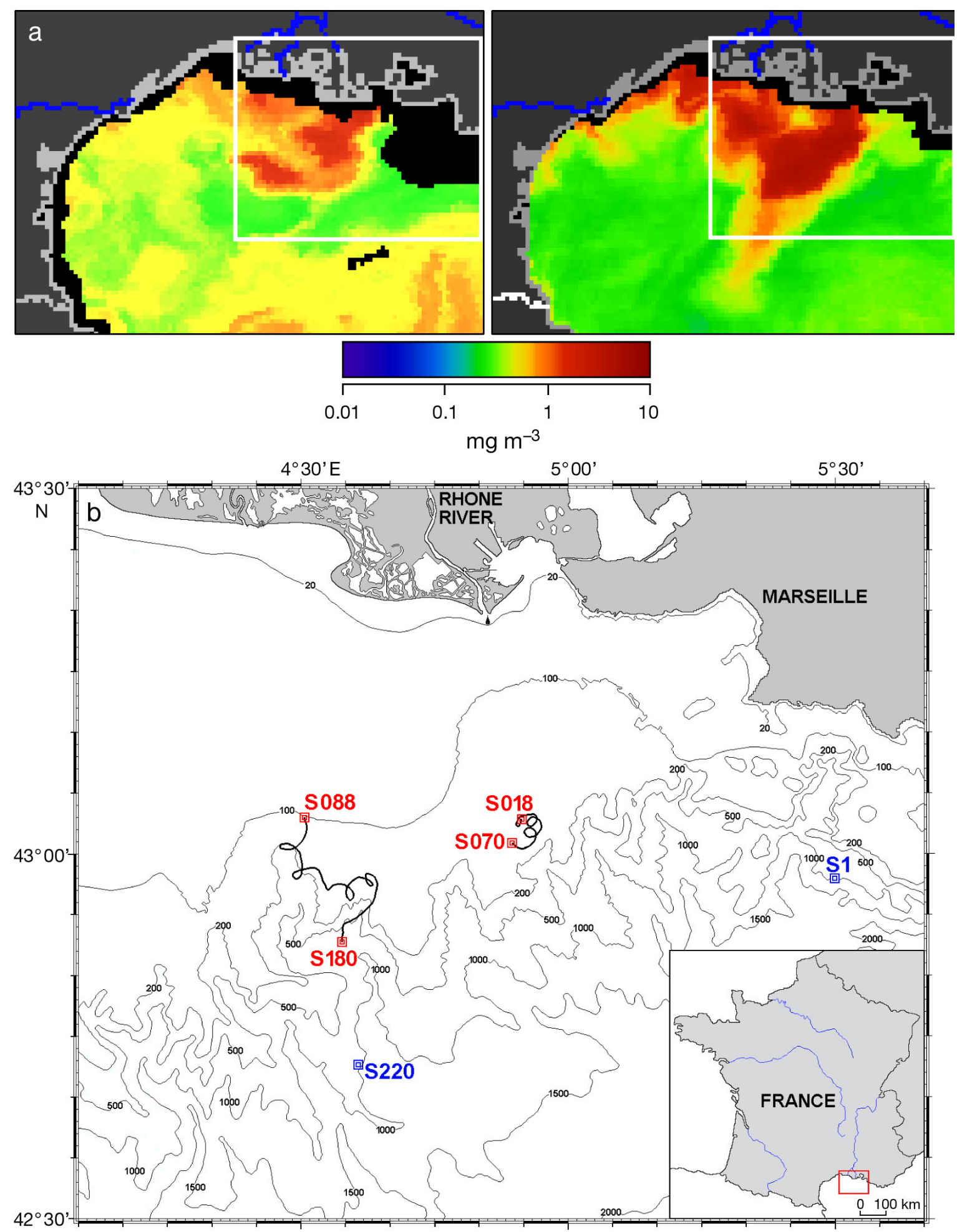

Fig. 1. (a) Chlorophyll a surface concentration based on MODIS satellite images (supplied by Joint Research Center, Ispra) of the Gulf of Lions on May 11 (upper left) and May 24 (upper right). The studied area is located in the white rectangle. (b) Detailed view of the studied area with the first trajectory $\left(43^{\circ} 00\right.$ to $43^{\circ} 03$ latitude and $4^{\circ} 54$ to $4^{\circ} 57$ longitude) with Stns S18 to S70, and the second trajectory $\left(42^{\circ} 53\right.$ to $43^{\circ} 03$ latitude and $4^{\circ} 28$ to $4^{\circ} 39$ longitude) with Stns S88 to S180. Two additional reference marine Stns S1 $\left(42^{\circ} 58\right.$ latitude, $5^{\circ} 30$ longitude) and S220 (42 42 latitude, $4^{\circ} 37$ longitude) were sampled at the beginning and the end of the cruise, respectively 
cence (Chelsea Aqua 3), light transmission (Seatech Wetlab Cstar), and oxygen (SBE 43). In addition to hourly CTD profiles, sampling was carried out every 2 , 6 or $12 \mathrm{~h}$, depending on the parameters considered. Water samples were collected from 121 Niskin bottles attached to the CTD-rosette system at depths of 5, 10, 15, 20 and $50 \mathrm{~m}$. The first trajectory included Stns S18 to S70, the second trajectory Stns S88 to S180 (Fig. 1b, Table 1).

In addition to the marine reference stations (S1 and S220) sampled at the start and end of the cruise, 5 other stations were sampled at each of the 5 depths during each deployment for HNF and ciliates. Fifteen and 29 stations were sampled at the $5 \mathrm{~m}$ depth only during the 1st and 2nd trajectories, respectively (Table 1).

To measure chl $a$, phytoplankton were collected by filtering $500 \mathrm{ml}$ of seawater through $47 \mathrm{~mm}$ GF/F glass fibre filters (Whatman). Pigment extraction, using $90 \%$ acetone, was processed immediately on board, with the extract kept for $12 \mathrm{~h}$ in the dark at $4^{\circ} \mathrm{C}$ and then centrifuged. Fluorescence properties of the supernatant were measured on a Hitachi F4500 spectrofluorometer operating in the ratio mode to determine chl a concentrations (Neveux \& Lantoine 1993). $\mathrm{NO}_{3}$, $\mathrm{NO}_{2}$ and $\mathrm{PO}_{4}$ were stored at $-20^{\circ} \mathrm{C}$ and analyzed within 1 mo of collection, according to Tréguer \& Le Corre (1975) on a Skalar auto-analyser.

Heterotrophic bacteria and pico- and nanophytoplankton. Abundance of pico- and nanophytoplankton was analysed onboard from freshly collected CTD bottle samples. Measurements for both communities were performed with a flow cytometer (FACSCan, Becton Dickinson) equipped with a $488 \mathrm{~nm}, 15 \mathrm{~mW}$ Argon laser. Phytoplanktonic cells were discriminated and enumerated according to right-angle light scattering properties (roughly related to cell size) and orange (FL2, 560 to $620 \mathrm{~nm}$ ) and red (FL3 >670 nm) fluorescence. Data acquisition was performed using CellQuest software, (BD-Biosciences). Fluorescent $1 \mu \mathrm{m}$ diameter beads (Polysciences), used as an internal standard, were systematically added to each analysed sample. For each discriminated population, cell fluorescence and light scatter emissions were normalised by dividing them by homologous bead properties, thereby making results comparable.

We distinguished 3 major groups of picophytoplankton: Synechococcus spp. (SYN, also characterised by orange fluorescence from phycoerythrin pigment); Prochlorococcus spp. (PRO) and photosynthetic picoeukaryotes (PIC). Three phototrophic nanoplanktonic cell types were also determined and characterised by apparent cell size and red fluorescence.

For counting of bacteria, seawater samples $(2 \mathrm{ml})$ were preserved with $2 \%$ (final conc.) formaldehyde, quickly frozen in liquid nitrogen and then stored at $-80^{\circ} \mathrm{C}$. Flow cytometric analysis was then carried out over the next 2 mo. Before analyses, samples were thawed at room temperature and stained with SYBR Green I (0.01\% vol/vol final conc., Molecular Probes). Bacteria were discriminated on a plot of their rightangle light scatter (roughly related to size) versus green fluorescence measured at 530/30 nm and related to nucleic acid content. From this cytogram, green fluorescence and light scatter from phytoplankton cells were excluded in order to obtain accurate heterotrophic cell counts.

To convert bacterial abundance to biomass, the conversion factor of $16.1 \mathrm{fg} \mathrm{C} \mathrm{Cell}^{-1}$ was used. This value was determined from biovolume measurements of samples stained with $2.5 \mu \mathrm{g} \mathrm{l}^{-1}$ of $4^{\prime}$-6'-diamidino-2phenylindole (DAPI) and using an epifluorescence microscoscope with semi-automated image analysis

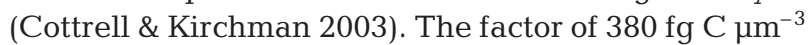
was then used to convert biovolume in biomass (Lee \& Fuhrman 1987). No significant differences in bacterial biovolume were observed between samples from the LSW and the MW (data not shown).

Bacterial production was measured by $\left[4.5-{ }^{3} \mathrm{H}\right]-$ leucine incorporation (Kirchman 2001) as described in

Table 1. Sampling dates and descriptions for heterotrophic nanoflagellates (HNF) and ciliates counts, and for grazing experiments. S1, S18 to S70, S88 to S180 and S200 define sampling stations. LSW: low salinity water. For time of grazing experiments and duration of each deployment see 'Materials and methods', and for station coordinates see Fig.1. -: marine stations were sampled once and there was no deployment at these stations

\begin{tabular}{|lcccc|}
\hline & 14/5/2006 & $\begin{array}{c}15-18 / 5 / 2006 \\
\text { 1st deployment }\end{array}$ & $\begin{array}{c}19-23 / 5 / 2006 \\
\text { 2nd deployment }\end{array}$ & 26/5/2006 \\
\hline Station designation & & S18 to S70 & S88 to S180 & S220 \\
Station type & S1 & LSW & Marine \\
Number of stations & Marine & 15 & 29 & 1 \\
Sampling duration (h) & 1 & 61 & 107 & - \\
Sampling frequency (h) & - & 2 or 12 & 2 or 12 & 1 \\
Number of surface samples (0-5 m) & - & 15 & 5 & 1 \\
Number of profiles (0-50 m) & 1 & 5 & 5 & 1 \\
Number of grazing experiments (5 m) & 1 & 5 & 5 & 1 \\
\hline
\end{tabular}


detail in Joux et al. (2009). Briefly, samples $(2.5 \mathrm{ml}$ in triplicate) were incubated in the dark at $18^{\circ} \mathrm{C}$ for $1 \mathrm{~h}$ with $2 \mathrm{nM}{ }^{3} \mathrm{H}$-Leu (specific activity $117 \mathrm{Ci} \mathrm{mmole}^{-1}$, Perkin Elmer) and $18 \mathrm{nM}$ of unlabelled leucine. The incorporated ${ }^{3} \mathrm{H}$-Leu was collected by micro-centrifugation after precipitation by trichloroacetic acid (TCA; $5 \%$ final conc.) and samples were rinsed with TCA and ethanol. Finally, the precipitates were re-suspended in $1 \mathrm{ml}$ of a liquid scintillation cocktail (FilterCount, Perkin Elmer) and radioactivity determined by liquid scintillation counter (LS 5000CE Beckman). Rates of live samples were corrected for adsorption of radioactivity with TCA-killed controls before addition of ${ }^{3} \mathrm{H}$ Leu. Incorporation rates were converted into carbon production using the conversion factor of $2.1 \mathrm{~kg} C$ produced per mole of leucine incorporated according to Gasol et al. (1998) for coastal water in the NW Mediterranean Sea during the summer season.

Heterotrophic nanoflagellates and ciliates. To enumerate HNF, 20 to $30 \mathrm{ml}$ samples were preserved using formaldehyde at a final concentration of $2 \%$ (Table 1 ). Samples were filtered onto black Nuclepore filters, (pore size: $0.8 \mu \mathrm{m}$ ) and stained with DAPI (Porter \& Feig 1980) within $5 \mathrm{~h}$ of sampling and stored at $-20^{\circ} \mathrm{C}$ until counting. HNF were enumerated using a LEITZ DMRB epifluorescence microscope at $1000 \times$. To distinguish between autotrophic and heterotrophic nanoflagellates, autofluorescence (chlorophyll) was determined under blue light excitation. HNF were divided into 5 size groups $(2-4$, $4-5,5-7,7-10$ and $>10 \mu \mathrm{m})$ and an average biovolume $\left(10.2,44.5,89,282\right.$ and $2188 \mu^{3}$, respectively) of each group was calculated based on the linear dimensions (length and width) of a total of 100 cells within each group using an image analyser with a camera mounted on the microscope. Biovolume of HNF was calculated on the assumption that their shape was ellipsoidal and was then converted to biomass using a conversion factor of

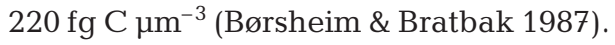

For ciliate enumeration, duplicate samples $(250 \mathrm{ml})$ were placed in opaque glass bottles. One $250 \mathrm{ml} \mathrm{sam-}$ ple was fixed with acid Lugol's solution (final conc. $2 \%$ ) for quantitative counts, and the other with boraxbuffered formaldehyde (final conc. $1 \%$ ) for determinations of the trophic type of the ciliates - heterotroph or mixotroph, based on the presence or absence of sequestered chloroplasts. The samples were then stored at $4^{\circ} \mathrm{C}$ in the dark until analysis (max. 3 mo later). The fixed samples were allowed to settle for $3 \mathrm{~d}$, with the supernatant being gently removed. This left $\sim 100 \mathrm{ml}$ of concentrate which was further sedimented in $100 \mathrm{ml}$ Hydrobios chambers for at least $24 \mathrm{~h}$ before enumeration using an Olympus IX-70 inverted microscope at $400 \times$ magnification. Lugol's fixed samples were enumerated and sized with phase contrast. The formaldehyde-fixed samples were examined using blue light ex- citation (DM $500 \mathrm{~nm}$ dichroic mirror, BP 450 to $480 \mathrm{~nm}$ exciter filter, BA $515 \mathrm{~nm}$ barrier filter and a $100 \mathrm{~W}$ mercury burner) to detect chlorophyll autofluorescence and to distinguish plastidic from non-plastidic ciliates.

Ciliates were identified wherever possible to genus or species level following Balech (1959), Maeda \& Carey (1985), Maeda (1986), and Laval-Peuto \& Rassoulzadegan (1988). Ciliates were further divided into 5 size

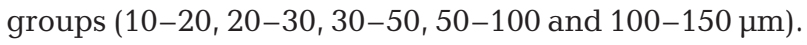
Linear dimensions (length and diameter) were measured at $400 \times$ magnification using an image analyser with a camera mounted on the microscope. Biovolumes of cells were calculated assuming the nearest geometrical shape; for this a minimum of 10 cells (for rare tintinnids) to a maximum of 100 to 120 cells (for the most abundant species such as Laboea strobila, Tontonia sp. Strombidium conicum and Myrionecta rubra) were measured. Biovolumes were converted to carbon biomass using a

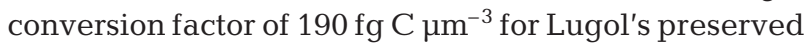
samples (Putt \& Stoecker 1989).

Grazing experiments. Twelve grazing experiments were performed, 10 in the LSW (5 during each deployment) and 2 in the MW (Table 1) on water sampled at $5 \mathrm{~m}$ and on one occasion also at $20 \mathrm{~m}$, during the 2nd deployment. The grazing experiments were conducted at $0,12,24,48,70 \mathrm{~h}$ and at $0,24,48,72$ and $96 \mathrm{~h}$ from the beginning of the first and second deployments, respectively.

Grazing by heterotrophic nanoflagellates: Duplicate bottles $(50 \mathrm{ml})$ were inoculated with $0.5 \times 10^{5} \mathrm{ml}^{-1}$ fluorescently labelled bacteria (FLB; stained with 5(4,6-dichlorotriazin-2-yl) aminofluorescein, DTAF) prepared a few weeks before the cruise from coastal MW using the protocol of Sherr et al. (1987). To produce FLB with the same variability in shape and volume as natural bacterioplankton, we concentrated and labelled natural bacteria without prior enrichment as described in Šimek et al. (2003). We determined HNF ingestion in sub-samples from short-time incubations of $15 \mathrm{~min}$ and $30 \mathrm{~min}$. The estimated in situ ingestion rate of HNF feeding on natural bacterioplankton (bact $\mathrm{HNF}^{-1} \mathrm{~h}^{-1}$ ) was then calculated by multiplying the ingestion rate of FLB by the ratio of bacteria to added FLB (Sherr et al. 1987).

Grazing by ciliates: Two types of fluorescently labelled prey (FLP) were prepared from early stationary cultures of the photosynthetic picoeukaryote Ostreococcus tauri (fluorescently labelled Ostreococcus, FLO, 0.8 to $1.5 \mu \mathrm{m}$ ), originally isolated in the Mediterranean Thau lagoon, France, (Courties et al. 1994) and Nannochloropsis sp. (211/78 CCAP culture collection; fluorescently labelled algae, FLA, 3 to $4 \mu \mathrm{m}$ in diameter), according to Rublee \& Gallegos (1989), detailed in Karayanni et al. (2005). The FLP act as analogues of pico- and nano-sized cells of similar diame- 
ters. We employed FLO as an analogue of Synechoccocus and phototrophic picoeukaryotes and FLA as an analogue of the smaller population of photosynthetic nanoplankton mostly represented by phototrophic nanoflagellates (PNAN) detected during this study by flow cytometry (3 to $5 \mu \mathrm{m}$ ).

Grazing experiments were conducted at the same stations and depths as for the bacterivory experiments. Water samples (1.2 l) were dispensed into polycarbonate bottles. One prey analogue, (FLO or FLA) was added to each sample in concentrations of $10^{3}$ FLO $\mathrm{ml}^{-1}$ or $10^{2}$ to $10^{3}$ FLA ml ${ }^{-1}$. After the addition of the prey analogues, subsamples were immediately taken for $\mathrm{T}_{0}$ counts of FLO and FLA. For ciliate food vacuole content analysis, $250 \mathrm{ml}$ subsamples were taken at 0 , 15 and 30 min and fixed immediately with $2 \%$ borate buffered formaldehyde. Samples were stored in the dark at $4^{\circ} \mathrm{C}$ until analysis by epifluorescence microscopy. Uptake rates of fluorescently labelled prey (FLO or FLA ciliate ${ }^{-1} \mathrm{~h}^{-1}$ ) were calculated for $15 \mathrm{~min}$ incubation times in most experiments, as after $30 \mathrm{~min}$ the average number of FLO or FLA per ciliate (CIL) had levelled off. The estimated in situ ingestion rate of ciliates feeding on pico- or nanoplankton (cells $\mathrm{CIL}^{-1} \mathrm{~h}^{-1}$ ) were then calculated by multiplying the ingestion rate of FLP by the ratio of abundances of natural prey to added FLP as for FLB.

\section{RESULTS}

\section{Characteristics of the study area}

During the BIOPRHOFI cruise, the daily Rhone River flow ranged from 1239 to $2292 \mathrm{~m}^{3} \mathrm{~s}^{-1}$ (mean: $1756 \mathrm{~m}^{3}$ $\mathrm{s}^{-1}$ ), with a $3 \mathrm{~d}$ peak discharge of over $2200 \mathrm{~m}^{3} \mathrm{~s}^{-1}$ from May 20 to 22. South-westward of the river mouth, a large dilution zone was associated with high surface chl $a$ as shown by the MODIS satellite images from May 11 and May 24, 2006 (Fig. 1a).

To distinguish the different water masses, and to relate them to the distributions of ciliates and HNF, we employed an averaged salinity profile calculated from the 146 hourly CTD casts recorded during the 2 trajectories. The LSW extended down to a maximum of $35 \mathrm{~m}$ depth with variable salinity $<38.25$, whereas the deeper MW was characterised by a constant increase of salinity with depth. Within the LSW, 2 water masses were distinguished: (1) the surface 'plume water' where salinity is highly variable (31.41 to 36.59$)$ lying between the surface and a depth of $5.25 \mathrm{~m}$, and (2) the intermediate 'diluted water' (salinity from 36.60 to 38.25 , Table 2) where salinity increasing with depth can be described by a 'power function'. The surface plume layer was also characterised by higher nutrient
Table 2. Physicochemial and biological parameters (mean \pm SD, min-max), in low salinity waters (LSW, both plume and diluted) and marine waters (MW). The separation of the 3 water types is based on salinity data. PNAN: phototrophic nanoflagellates, BP: bacterial production, HNF: heterotrophic nanoflagellates, und: undetectable

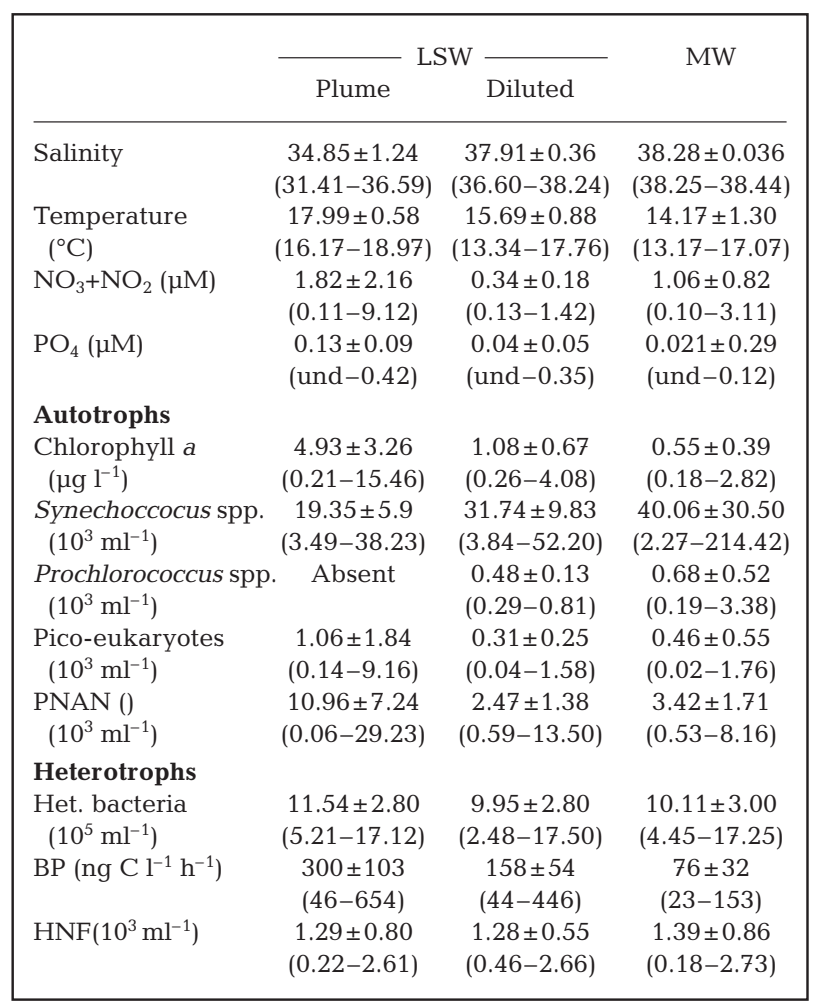

concentrations compared to the underlying diluted water or the surrounding MW (Table 2, Fig.2). The highest concentration of chl a was found in the plume water (up to $15.5 \mathrm{\mu g} \mathrm{l}^{-1}$ ), while diluted water was on average 2-fold higher than in the MW (Table 2, Fig. 2).

\section{Autotrophic pico- and nanoplankton}

Pico- and nanoautotrophs showed contrasting abundance in the 3 water types. Prochlorococcus spp. was absent in the plume waters but found in relatively low concentrations of a few hundred cells per milliliter in the diluted and MW. Synechococcus spp. was present in the 3 water types, showing a higher average concentration in the MW (Table 2). Pico- and nanoeukaryotes were more abundant in the LSW than in the surrounding MW. Picoeukaryotes were on average about 2-fold more abundant in the plume waters, and showed similar abundance in diluted and MW. Nanoautotrophs, which were abundant in all the 3 water types, showed on average a 3 to 5 fold higher abundance in the plume waters compared to marine and diluted waters (Table 2). 


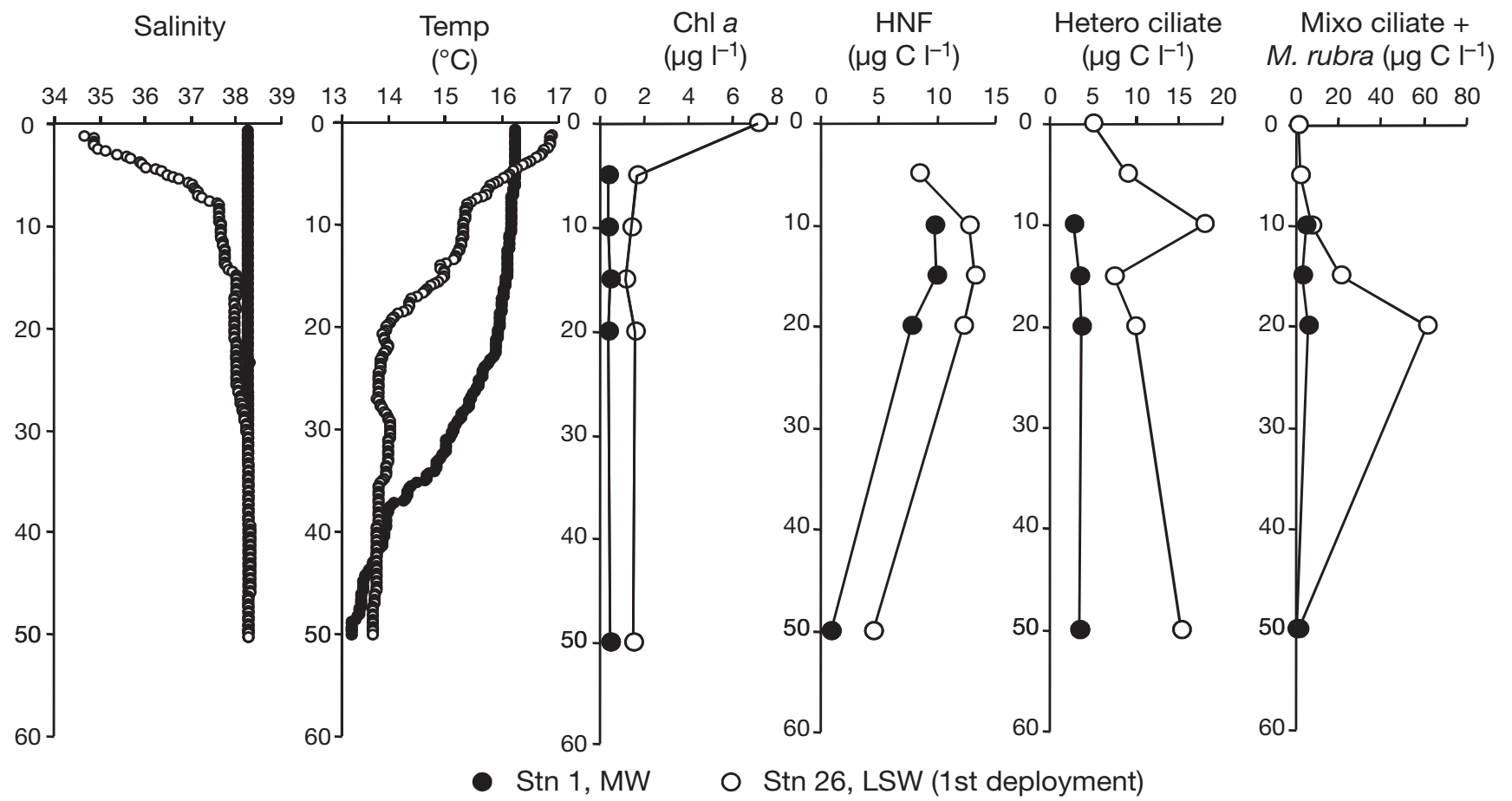

Fig. 2. Typical vertical distribution of salinity, temperature, chlorophyll a concentration, heterotrophic flagellates (HNF), heterotrophic (hetero) ciliates and mixotrophic (mixo) ciliates + Myrionecta rubra for the marine water (MW) Stn S001 (closed symbols) and the low salinity water (LSW) Stn S026 (open symbols) (cf. Fig.1, Table 1)

\section{Abundance and biomass of heterotrophic bacteria, HNF and ciliates: relations to bacterial production}

The mean abundance and the range of heterotrophic bacteria and HNF were similar in the plume, diluted and MW. In contrast, bacterial production was on average about 2- and 4 -fold higher in the diluted and plume waters, respectively, compared to the marine samples (Table 2, Fig. 2). The majority of HNF were small, ( 70 to $>80 \%$ of the population $<5 \mu \mathrm{m}$ ) and did not appear to follow any clear abundance or biomass pattern. We examined the functional relationship between HNF and bacteria by plotting log-log values of bacterial versus HNF abundance (Fig. 3) following the model of Gasol (1994). The resulting plot of log HNF abundance (HNF, cells $\mathrm{ml}^{-1}$ ) and log bacterial abundance $\left(\mathrm{ml}^{-1}\right)$ seems to suggest that HNF were always well below the carrying capacity of the system (Gasol 1994), and that they were bottom-up and/or top-down controlled without any clear differentiation according to the water type (Fig. 3).

\section{Ciliate abundance and biomass}

The ciliate community structure was similar in both the LSW and the MW, and was characterised by the dominance, both in number and biomass, of mixo- trophs (Laboea strobila, Tontonia spp. and Strombidium conicum), Mesodinium rubrum, (Myrionecta rubra), and Myrionecta sp. traditionally reported as only being autotrophic, but now identified as also

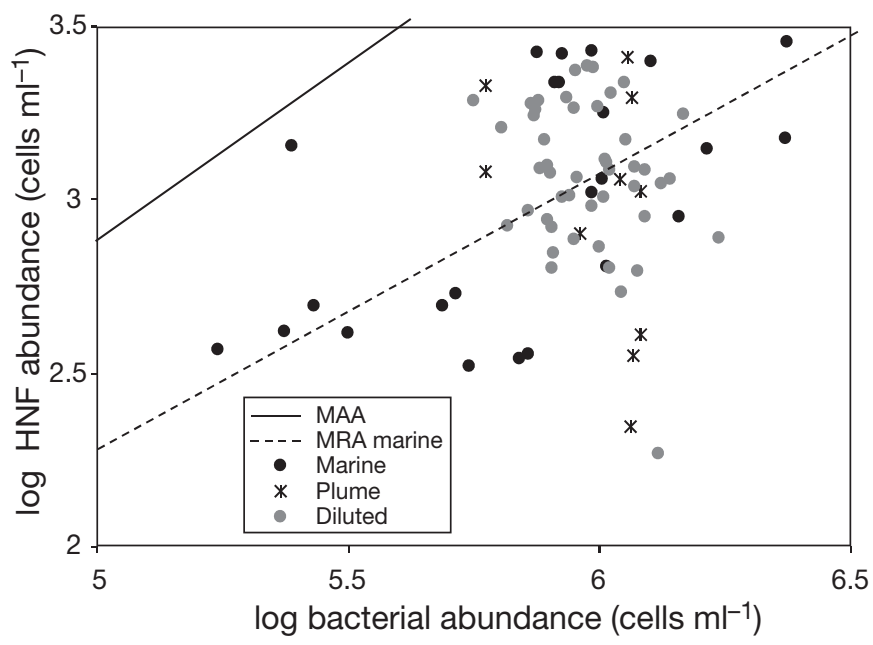

Fig. 3. Relationship between log heterotrophic nanoflagellates abundance (HNF) and log bacterial prey. The solid line and dashed line represent the maximum attainable abundance (MAA) and mean realised abundance (MRA) for marine environments, following Gasol (1994). HNF abundances fall below the MAA and no differentiation between bottom-up or top-down control can be made among the 3 water types (marine, plume and diluted) 
being occasionally mixotrophic (Gustafson et al. 2000, Yih et al. 2004, Myung et al. 2006). For easier interpretation of the figures we included chlorophyll containing ciliates (mixotrophs + M. rubra) in Fig. 2 but we also give their abundance and biomass separately (Table 3). Among heterotrophic aloricate ciliates, Lohmaniella ovalis, S. sphaericum, S. compressum, S. crassum, S. spiralis, Strombidium spp. and scuticociliates were present in all samples, usually in low numbers and biomass. Tintinnids of the genera Eutintinnus, Amphorella and Tintinnopsis were present in marine water in low numbers and accounted for 1 to $16 \%$ (mean $9 \%$ ) of the biomass. Tintinnids were only sporadically present in the LSW samples, where they represented 0 to $14 \%$ of the biomass (mean $1 \%$ ).

Comparing the diluted and plume waters to the MW, the mean abundance of total ciliates was about 3- to 4fold higher in the diluted and plume waters relative to MW (Table 3). It is worth noting that this difference was due to the mixotrophic ciliates, which were about 4- to 5fold more important in the LSW, while heterotrophic ciliates only increased by a maximum of 2-fold. Myrionecta rubra was the most abundant species, reaching 4600 cells $\mathrm{l}^{-1}$ in the plume (S139: $5 \mathrm{~m}$ ), while Laboea strobila was dominant in terms of biomass, accounting for $47 \%$ of total biomass in the LSW (Table 3). Log-transformed data of ciliate abundance and chl a concentration indicated significant relationships for both heterotrophic and mixotrophic ciliates. The $y$-intercept for mixotrophs was slightly higher than that estimated for the heterotrophs (Fig. 4) but there was no difference between the slopes $\left(t=0.009, t_{(0.05,70)}=1.994\right.$ tested according to Zahr 1984).

\section{Langrangian sampling of heterotrophic protists}

The Langrangian sampling of heterotrophic protists was performed at $5 \mathrm{~m}$ depth. At this depth, which was close to the interface between plume and diluted water, salinity showed marked variability from 33.46 to 37.79 (Fig. 5a,b). The lower salinity waters were gener-

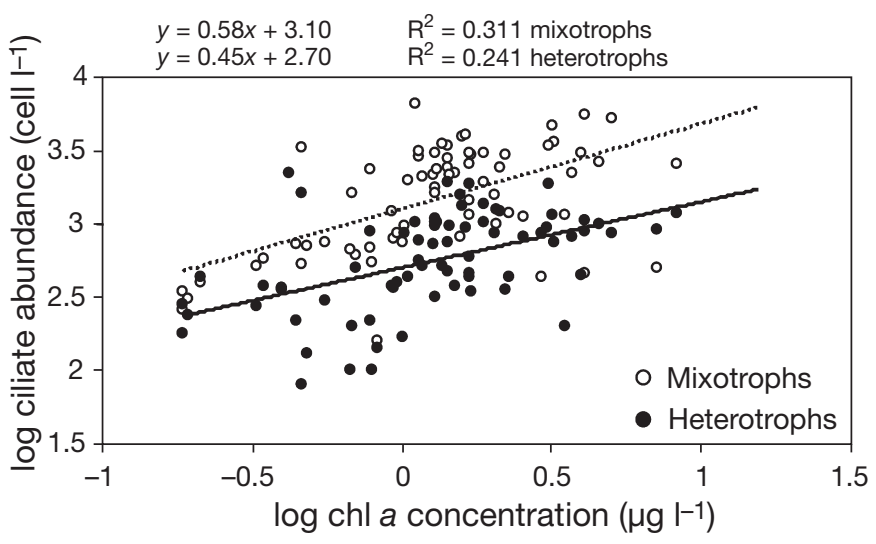

Fig. 4. Relation between log chlorophyll a concentration and $\log$ ciliate abundance. Solid and dashed lines represent the linear regressions for heterotrophs and mixotrophs, respectively

ally richer in chl $a$ and phototrophic nanoflagellates (PNAN, Fig. 5 a,b,e,f), with significant negative correlations between concentrations and salinity $(\mathrm{r}=-0.59$, $\mathrm{r}=-0.63$ respectively, $\mathrm{n}=45, \mathrm{p}<0.0001)$. Bacterial, HNF and ciliate abundance estimates were highly variable; this sometimes coincided with important shifts in salinity - e.g. the highest ciliate numbers during the 2nd deployment were at $72 \mathrm{~h}$, when salinity decreased significantly (Fig. 5 c-f). However, abundance estimates were not generally correlated with salinity at the $5 \mathrm{~m}$ depth. The coefficient of variation of the $5 \mathrm{~m}$ data was larger for chl $a$ and PNAN, at 60 and $70 \%$, respectively, than estimates describing the heterotrophs, which were $\sim 55 \%$ for ciliates, $48 \%$ for $\mathrm{HNF}$ and only $22 \%$ for bacteria.

\section{Ciliate ingestion of pico- and nano-algae}

Fluorescently labelled prey uptake experiments permitted the determination of the feeding characteristics of different ciliates separately. Because the samples taken contained quite large numbers of recognisable ciliates,

Table 3. Ciliate abundance and biomass (mean \pm SD, min-max), in low salinity waters (LSW, both plume and diluted) and marine waters (MW). The separation of the 3 water types is based on salinity data (see Table 2). Abund: abundance; Myrionecta rubra; Laboea strobila

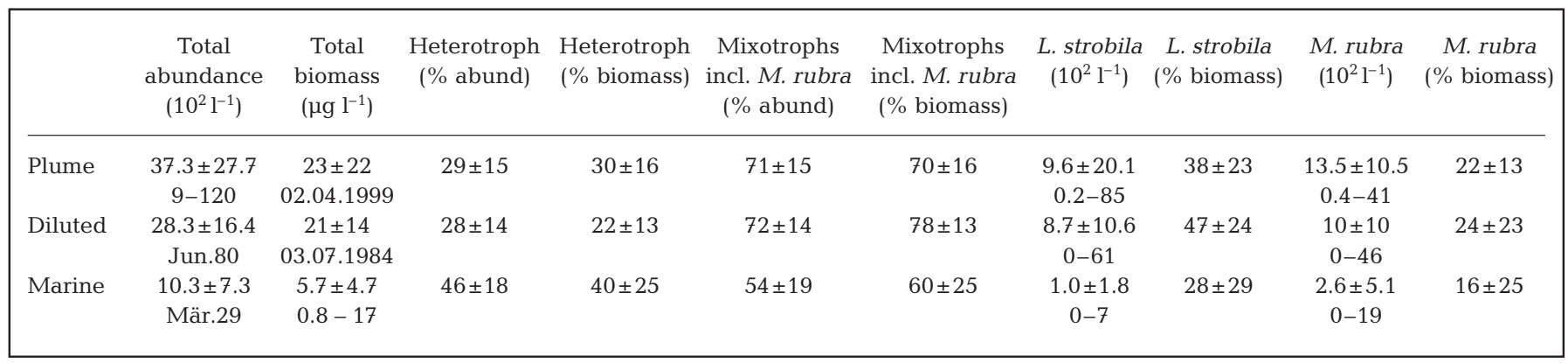



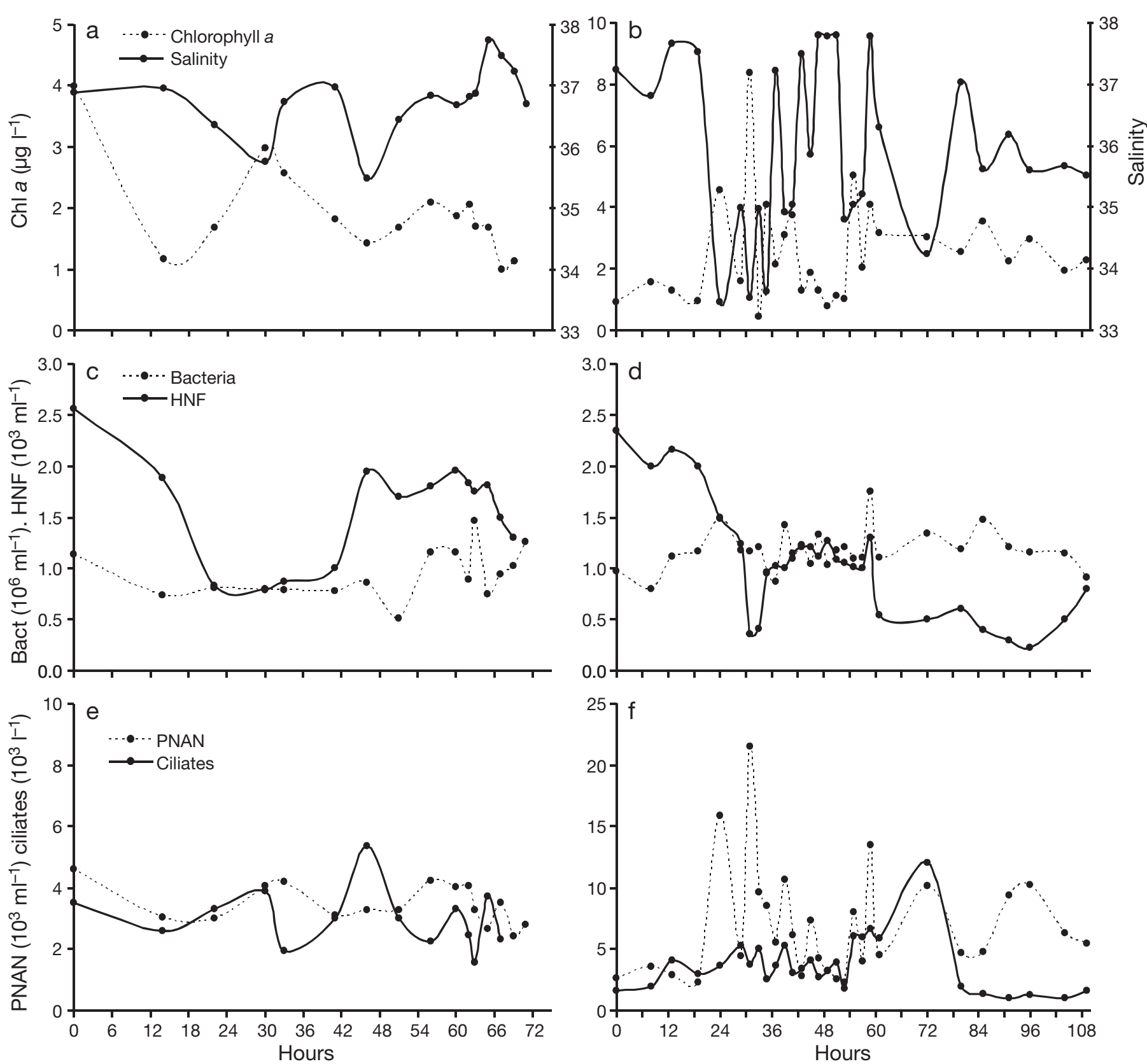

Fig. 5. Chlorophyll a ( $\mathrm{chl}$ a), salinity, heterotrophic nanoflagellates (HNF), bacteria (bact), total ciliates and photototrophic nanoflagellates (PNAN) at $5 \mathrm{~m}$ depth during the first $(\mathrm{a}, \mathrm{c}, \mathrm{e})$ and the second $(\mathrm{b}, \mathrm{d}, \mathrm{f})$ deployment

we were able to estimate ingestion rates and the distribution of ingested prey for the individual species Laboea strobila, Tontonia spp. and Strombidium conicum, while the aloricate heterotrophs, which were less abundant, were considered as 1 group (Fig. 6). It should be noted that Myrionecta rubra was not observed ingesting any of the prey it was offered, and as a result we were unable to evaluate whether it showed grazing activity or not.

The frequency distribution of ingested prey per ciliate cell varied between different species/groups and prey offered. Overall, all ciliates seemed to prefer FLA over FLO of smaller size, and also mixotrophs showed higher ingestion rates than heterotrophs (Fig. 6). Based on size, we employed FLO as analogues for Synechococcus spp. and picoeukaryotes, while FLA were analogues of the smaller PNAN cells (see 'Materials and methods'). We found that Labeoa strobila was the most important grazer (Fig. 6). The other mixotrophic species studied showed lower rates of prey uptake. Most of the aloricate heterotrophs present in the samples showed moderate uptake of FLA (Fig. 6, Table 4). Based on FLA uptake, the mean ingestion rate of $L$. 


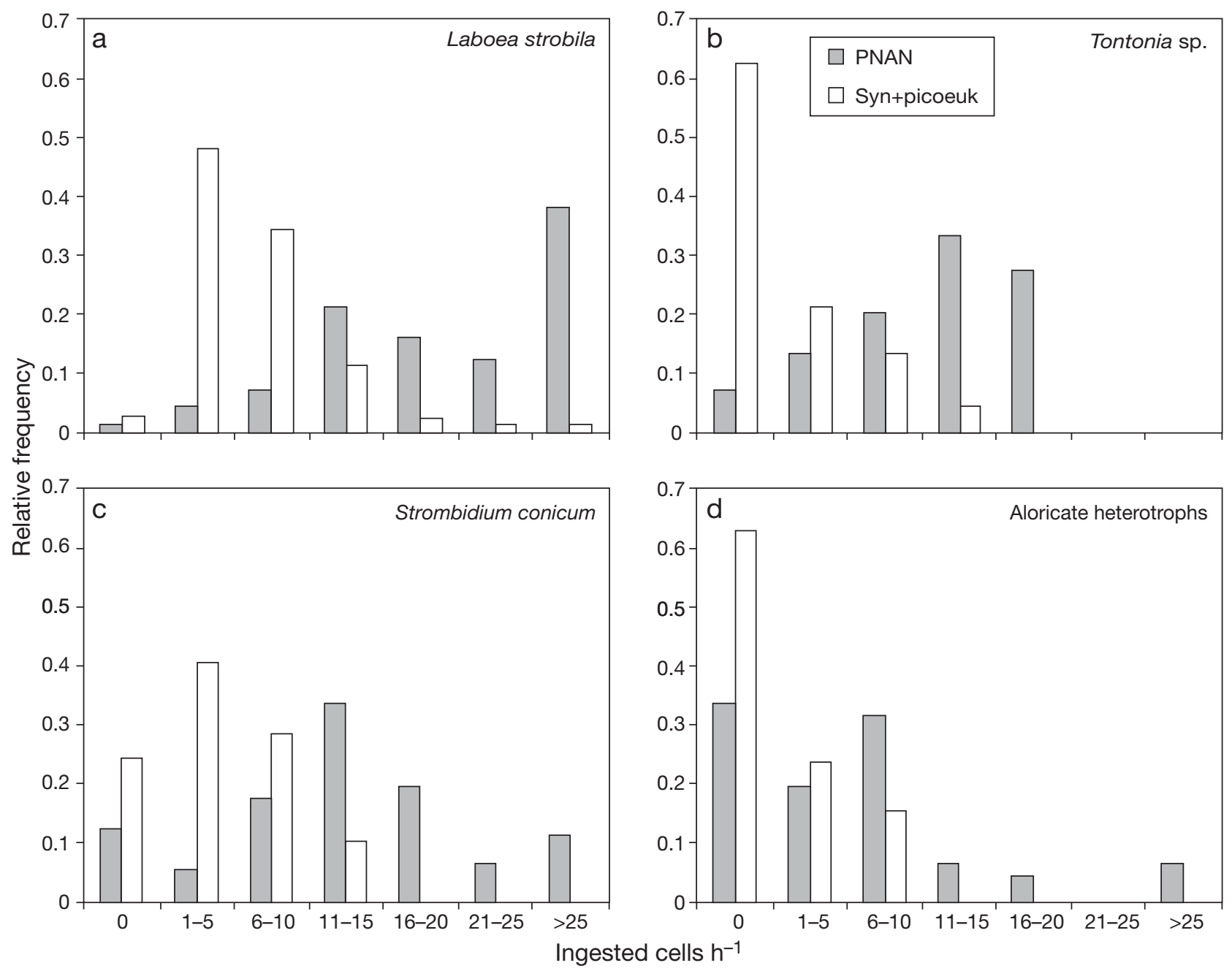

Fig. 6. Frequency distribution of ingested prey in (a) Labeoa strobila, (b) Tontonia sp., (c) S. conicum and (d) aloricate heterotrophs. Photototrophic nanoflagellates (PNAN) is based on fluorescently labelled algae (FLA) $(4-5 \mu \mathrm{m})$ ingestion and Synechococcus spp. (Syn) and picoeukaryote (picoeuk) is based on fluorescently labelled Ostreococcus (FLO) (0.8-1.5 $\mu \mathrm{m}$ ) ingestion

Table 4. Consumption parameters of ciliates: \% of the PNAN stock grazed per day by total ciliates, mixotrophs and heterotrophs, based on FLA uptake. For comparison, PNAN consumption based on potential clearance rate of $10^{5}$ body volumes $\mathrm{h}^{-1}$ (Fenchel 1980; Jonsson 1986) is also presented. n: number of measurements; MW: marine water; PNAN: phototrophic nanoflagellates

\begin{tabular}{|c|c|c|c|c|}
\hline & \multirow[b]{2}{*}{ Total ciliates (mean \pm SD) } & \multirow[b]{2}{*}{ Mixotrophs } & \multirow{2}{*}{$\begin{array}{l}\% \text { PNAN d }^{-1} \\
\text { Heterotrophs }\end{array}$} & \multirow[b]{2}{*}{$\left(10^{5}\right.$ ciliate body volume $\mathrm{h}^{-1}$} \\
\hline & & & & \\
\hline Plume $(n=5)$ & $64 \pm 5$ & 50 & 14 & 50 \\
\hline Diluted $(n=5)$ & $56 \pm 6$ & 44 & 12 & 54 \\
\hline Stn 1, MW (n = 1) & $12 \pm 4$ & 6 & 6 & 26 \\
\hline Stn $220, \mathrm{MW}(\mathrm{n}=1)$ & $7 \pm 2$ & 4 & 3 & 12 \\
\hline
\end{tabular}

strobila, Tontonia spp., Strombidium conicum, and aloricate heterotrophs was 26, 15, 14 and 8 PNAN h$^{-1}$, respectively. Based on these ingestion rates and the number of similar size PNAN measured by flow cytometry, ciliates ingested 7 and $12 \%$ in the MW and about $60 \%$ of the PNAN stock in the LSW (Table 4 ). In con- trast, the impact of ciliate ingestion on the Synechococcus spp. and picoeukaryote stock, calculated from the ingestion rate of FLO, was very low as it represented only from 0.03 to $4.77 \%$ (mean \pm SD: $0.77 \pm 0.76$ ) of the stock of Synechococcus spp. + picoeukaryotes, pooling all the experiments. 


\section{Bacterial ingestion by heterotrophic nanoflagellates}

Bacterial ingestion by HNF based on FLB uptake showed differences between marine and the LSW waters (Table 5). The ingestion and clearance rates were higher in the LSW than in MW. Reasoning in terms of bacterial stock, the turnover of bacterial stock was about 3-fold higher in the LSW than in the MW (Table 5). However, the bacteria present in the LSW were far more active than those in the MW so that for relatively similar numbers of bacteria much higher BP was measured in the LSW (Table 2). Thus, if we consider the impact of HNF grazing relative to bacterial production, a higher \% of BP was consumed in MW, suggesting that the pathway of bacterial carbon transfer to higher trophic levels via HNF was more important in those waters (Table 5). The ingestion of FLO was very low and ranged between 0 and 0.2 FLO $\mathrm{HNF}^{-1} \mathrm{~h}^{-1}$. For this reason these results have not been further analysed.

\section{DISCUSSION}

\section{Abundance and biomass of heterotrophic nanofla- gellates and relationships to bacterial production}

In contrast to the basic parameters such as chl $a$ and ciliate abundance, the mean bacterial and HNF abundance and biomass were quite similar in all 3 water types examined during the study. The relative stability of bacterial numbers in the LSW and MW indicates that bacterial production was tightly matched by bacterial mortality. The fate of bacteria - whether they are ingested by protists or lysed by viruses - is relevant to how much of the bacterial carbon is made available for higher trophic levels through grazing, or is mineralised within the microbial food web. Our rate estimates suggest that although HNF ingested more bacteria per hour in the LSW, they consumed $<30 \%$ of $\mathrm{BP} \mathrm{d}^{-1}$, while they consumed almost $60 \%$ of BP in MW (Table 5). We are quite confident about the CFs used in this study. Bacterial carbon content was determined by biovolume measurements and for leucine incorporation we employed an CF previously determined for NW Mediterranean coastal waters (Gasol et al. 1998, Pedròs-Aliò et al. 1999). CFs for open waters tend to be lower (Pedrós-Alió et al. 1999, $0.34 \mathrm{~kg} \mathrm{C} \mathrm{mol}^{-1}$ ); therefore, if we had used open water CFs here for MW, the effect of HNF on BP would have been greater, resulting in consumption rates $>100 \%$.

Rates of bacterial consumption that are relatively low, compared to rates of bacterial production, have been reported from a variety of chl a rich waters (e.g. Wieltschnig et al. 1999, Christaki et al. 2008). In the present study, a higher ratio of virus-like particles to bacteria was found in the LSW compared to MW (F. Joux unpubl. data), suggesting that in the LSW viral lysis could be a significant control mechanism of bacterial biomass production, a possibility which deserves further attention.

\section{Abundance and biomass of ciliates}

We found that, while the composition of the ciliate community did not differ between the LSW and the MW, the LSW was characterised by higher abundance and dominance by mixotrophs. Furthermore, these mixotrophs had high ingestion rates on nanophytoplankton. During the second deployment, the abundance of ciliates at $5 \mathrm{~m}$ depth showed important fluctuations (Fig. 5) which may not only be related to salinity variations at the interface between plume and diluted water, but may also indicate a tendency towards patchy distribution of these organisms (Crawford \& Lindholm 1997). The taxonomic composition of the ciliate community was dominated by naked oligotrichs (Strombidium spp., Labeoa strobila, Tontonia spp.) and the haptorid Myrionecta rubra. High percentages of mixotrophs within the ciliate community are common, and have been previously reported in a variety of neritic waters (e.g. Stoecker et al. 1987, 1989, Sanders 1995, Crawford \& Lindholm 1997, Modigh 2001). In particular, the dominant species found in the present study, L. strobila and M. rubra, are euryaline (3 to

Table 5. Consumption parameters of heterotrophic flagellates (HNF): mean values of ingestion rates (IR), clearance rates (CR), \% of bacterial stock (BB), bacterial production (BP) consumed per day and \% bacterial biomass turnover. Calculations of \% BP consumed and biomass turnover were calculated with a conversion factor of $16 \mathrm{fg} \mathrm{C}$ bact. $^{-1}$ (see 'Materials and methods'). $\mathrm{n}=\mathrm{number}$ of measurements

\begin{tabular}{|lccccc|}
\hline & $\begin{array}{c}\mathrm{IR} \\
(\text { bact. HNF }\end{array}$ & $\begin{array}{c}\mathrm{CR} \\
\left.\mathrm{h}^{-1}\right)\end{array}$ & $\begin{array}{c}\text { \% BB } \\
\left(\mathrm{d}^{-1}\right)\end{array}$ & $\begin{array}{c}\text { \% BP } \\
\left(\mathrm{d}^{-1}\right)\end{array}$ & $\begin{array}{c}\text { \% BB turnover } \\
\left(\mathrm{d}^{-1}\right)\end{array}$ \\
\hline Plume $(\mathrm{n}=5)$ & 3.5 & 3.6 & 10 & 25 & 37 \\
Diluted $(\mathrm{n}=5)$ & 2.5 & 2.5 & 9 & 38 & 26 \\
Marine $(\mathrm{n}=2)$ & 1.6 & 1.8 & 6 & 59 & 10 \\
\hline
\end{tabular}


$40^{\circ} \mathrm{C}$ ) and eurythermic ( 0 to $24^{\circ} \mathrm{C}$ ) organisms known to occur in high numbers and biomass in coastal waters (McManus \& Fuhrman 1986, Stoecker al. 1987, Sanders 1995, Modigh 2001). These ciliates are both producers and consumers, and models of marine food webs suggest that mixotrophy results in increased trophic efficiency in the sea (Stickney et al. 2000).

During the present study, abundance of ciliates in the LSW was of the order of $10^{3}$ to $10^{4} \mathrm{l}^{-1}$ and had a mean biomass of $20 \mu \mathrm{C} \mathrm{Cl}^{-1}$ (Table 3). Relative to the concentrations of total ciliates, the peak concentrations of Myrionecta rubra in the LSW $\left(4.6 \times 10^{3}\right.$ cells $\mathrm{l}^{-1}$, Table 3) were high. However, the concentrations were about 1 order of magnitude less than peak concentrations reported from a variety of systems, usually under stratified conditions. For example, Modigh reported abundances in the Gulf of Trieste of up to $49 \times 10^{3}$ cells $1^{-1}$ (Modigh 2001), and in an estuary of the Gulf of Maine up to $37 \times 10^{3}$ cells $1^{-1}$ were found (Sanders 1995). In contrast, Laboea strobila was much more abundant in our samples (up to $8.5 \times 10^{3}$ cells $\mathrm{l}^{-1}$ ) relative to previous studies (up to 775 cells $1^{-1}$ and $\approx 1.5 \times$ $10^{3}$ cells $1^{-1}$ in Sanders 1995, Modigh 2001, respectively). However, Dutz \& Peters (2008) reported that in the North Sea, L. strobila dominated the ciliate community and had an average biomass of $48.3 \mu \mathrm{g} \mathrm{C}^{-1}$, which is about 4 times the biomass found in our samples (Table 3).

\section{Ciliated ingestion of pico- and nano-algae}

Among the various methods applied to measure protistan grazing (e.g. dilution experiments, disappearance of prey), the direct examination of FLP inside digestive vacuoles has the advantage of illustrating the identities of the grazers and their individual contributions to the overall grazing rate. As with all grazing detection methods, the use of fluorescent particles has its known limitations, including the possible underestimation of grazing rates due to negative selection of prey. FLP techniques have been widely discussed in previous studies (e.g. Vazquez-Dominguez et al. 1999, Vaqué et al. 2002). Aside from these methodological limitations, our results substantiate the clear pattern observed between marine and low salinity waters with higher grazing rates due to mixotrophic ciliates, in particular Laboea strobila (Fig. 6, Table 4). Another important observation concerns the abundance of Myrionecta rubra, which did not ingest either prey offered. M. rubra can function phototrophically for extended periods without ingesting prey, but feeding is periodically required for optimal growth and photosynthesis, especially in high light levels (Johnson \& Stoecker 2005). Yih et al. (2004) showed that M. rubra can become an important grazer of cryptophytes after starvation. Consequently, the non-uptake of prey in our experiments by $M$. rubra can be explained by a dominance of phototrophic function during the sampling period, but one can also assume that this organism is very discriminating in its feeding, and consequently, did not select the prey used in this experiment.

In the open N Atlantic, it has been shown that ciliates, in particular Tintinnids, are capable of ingesting fluorescently labelled Synechococcus $(\approx 1 \mu \mathrm{m})$ at high rates during the winter (Karayanni et al. 2005). To cover a larger size range of prey, we included Ostreococcus tauri in our experiments to simulate grazing on autotrophic picoeukaryotes which can be very abundant in coastal environments (e.g. Iriarte \& Purdie 1994); ciliates showed very low ingestion on picoplankton analogues. It is probable that mixotrophic ciliates were preferentially ingesting nano-sized prey; however the low ingestion by aloricate heterotrophs may represent a selection against FLO.

As a consequence of their high concentration $\left(10^{3}\right.$ to $10^{4}$ cell $\mathrm{ml}^{-1}$ ), PNAN may be an abundant food source for ciliates in the diluted and plume waters. The ciliate -chl a relationship indicates a coupling with the phytoplankton stock (Fig. 4). The ratio of ciliate carbon to chl $a$ in open MW has been reported to range from 2 to 5 (Dolan \& Marasé 1995, Dolan et al. 1999). Claessens et al. (2008) have recently reported values from 2 to 26 in the oligotrophic Red Sea. According to these authors, the higher this ratio, the higher the efficiency of ciliates in using algae as a food source. We applied this approach to the present data and compared it with the trends we found using our grazing measurements. Throughout the duration of the present study, the ciliate carbon:chl a ratio showed great variability (from 2 to $>50$ ), with mean values of 5, 21 and 10 for plume, diluted and MW, respectively. This hierarchy of values is in accordance with our grazing measurements on PNAN for marine and diluted waters (Table 4), but not for plume waters, where very high values of chl a were occasionally recorded. As reported by Diaz et al. (2008) on the 'ecological maturity' of the Rhone River plume or by Dagg et al. (2004) on the Mississippi River, this could be related to a shorter residence time for plume water, where ciliate growth is not yet at its maximum, compared to diluted water which has a higher residence time.

We made an additional comparison to evaluate our estimates of grazing rates by calculating a theoretical grazing rate of ciliates feeding on PNAN based on ciliate biovolume measurements - with a clearance rate of $10^{5}$ body volumes $\mathrm{h}^{-1}$ (Fenchel 1980, Jonsson 1986). In the case of plume and diluted waters, the result obtained with this semi-theoretical approach was close to that measured by FLA uptake in the 
LSW, whereas it was 2-fold higher for MW (Table 4). In conclusion, even though the percent of consumption measured by the FLA may have been subject to some inaccuracies, the bulk of the evidence supports the observation that ciliates, and in particular mixotrophs, were very active in the LSW where they grazed on phytoplankton at near their maximum clearance capacities (Table 4). Ciliates in the LSW, by repackaging the small algal prey into accessible particles, are an important intermediate link to higher trophic levels.

Besides phytoplankton, ciliates can use other heterotrophs such as HNF and heterotrophic bacteria as alternative food sources (e.g. Karayanni et al. 2008 and references therein). From a methodological point of view, direct measurement of HNF uptake can be very complex. The HNF-bacteria log-log relationship does not show any trend of prevailing top-down control on HNF in the LSW where ciliates are very abundant (Fig. 3). Our suggestion is that mixotrophs, which dominated the ciliate population, may discriminate against HNF in favour of chloroplast-containing prey. Our data suggest that during the present study the overall grazing pressure on HNF and heterotrophic bacteria by ciliates was moderate.

Our results describing the community structure and the trophic role of nano- and microzooplankton in the diluted mesoscale structures of the Rhone River provide a number of new insights into the functioning of coastal ecosystems enriched by riverine input. We have shown in the present study that the microbial food web, and in particular mixotrophs, represents an important link from photosynthetically-fixed carbon transfer to higher trophic levels in this ecosystem. Microzooplankton are also important contributors to the diet of mesozooplankton (e.g. Christaki \& Van Wambeke 1995), and it has been shown recently that large ciliates, in particular Laboea strobila, are an excellent food source for the reproduction of the copepod Acartia clausi in the North Sea (Dutz \& Peters 2008). During the BIOPHOFI cruise, the abundance and biomass of copepods was several fold higher in the LSW (D. Bonnet, unpubl. data). Further investigation in this system should focus on the transfer of ciliate biomass to copepods and/or directly to fish; such information could then be considered in fisheries predictive models.

Acknowledgements: This study was supported by the French Programme National d'Environnement Côtier (PNEC) Chantier Méditerranée of the Institut National des Sciences de l'Univers (INSU). This work was also funded through a National Science Foundation Office of International Science and Engineering US-France Cooperative Science Program grant 0340764 to W.H.J. We thank the crew of the R.V. 'Le Suroît', from IFREMER, for making the cruise so successful.
We thank N. Batailler and L. Oriol for microscopic determination of bacterial biovolume and nutrient analysis, respectively. We thank the reviewers for their constructive comments and P. Magee for correcting the language. As this special issue is dedicated to F. Rassoulzadegan, it is particularly rewarding that our paper has highlighted the fact that ciliates, in particular mixotrophs, can be an important link in food web transfer.

\section{LITERATURE CITED}

Balech E (1959) Tintinnoinea del Mediterraneo. Trabajos del Instituto Espanol de Oceanografia, Madrid, No 28

Bernard C, Rassoulzadegan F (1994) Seasonal variations of mixotrophic ciliates in the northwest Mediterranean Sea. Mar Ecol Prog Ser 108:295-301

Børsheim KY, Bratbak G (1987) Cell volume to cell carbon conversion factors for a bacterivorous Monas sp. enriched from sea water. Mar Ecol Prog Ser 36:171-179

Bosc E (2002) Variations saisonnières et interannuelles de la biomasse phytoplanctonique et de la production primaire en Méditerranée: évaluation et utilisation des données satellitales de couleur de l'Océan. PhD thesis, Université de Toulon et du Var, Toulon

Calbet A, Saiz E (2005) The ciliate-copepod link in marine ecosystems. Aquat Microb Ecol 38:157-167

Christaki U, Van Wambeke F (1995) Simulated phytoplankton bloom input in top-down manipulated microcosms: comparative effect of zooflagellates, ciliates and copepods. Aquat Microb Ecol 9:137-147

Christaki U, Giannakourou A, Van Wambeke F, Gregori G (2001) Nanoflagellate predation on auto and heterotrophic picoplankton in the oligotrophic Mediterranean Sea. J Plankton Res 23:1297-1310

Christaki U, Obernosterer I, Van Wambeke F, Veldhuis M, Garcia N, Catala P (2008) Microbial food web structure in a naturally iron fertilized area in the Southern Ocean (Kerguelen Plateau). Deep-Sea Res II 55:706-719

Claessens M, Wickham SA, Post AF, Reuter M (2008) Ciliate community in the oligotrophic Gulf of Aqaba, Red Sea. Aquat Microb Ecol 53:181-190

Cottrell MT, Kirchman DL (2003) Contribution of major bacterial groups to bacterial biomass production (thymidine and leucine incorporation) in the Delaware Estuary. Limnol Oceanogr 48:168-178

> Courties C, Vaquer A, Troussellier M, Lautier J and others (1994) Smallest eucaryotic organism. Nature 370:255

Crawford DW, Lindholm T (1997) Some observations on vertical distribution and migration of the phototrophic ciliate Mesodinium rubrum (= Myrionecta rubra) in a stratified brackish inlet. Aquat Microb Ecol 13:267-274

> Dagg M, Benner R, Lohrenz S, Lawrence D (2004) Transformation of dissolved and particulate materials on continental shelves influenced by large rivers: plume processes. Cont Shelf Res 24:833-858

> Diaz F, Naudin JJ, Courties C, Rimmelin P, Oriol L (2008) Biogeochemical and ecological functioning of the low-salinity water lenses in the region of the Rhone River freshwater influence, NW Mediterranean Sea. Cont Shelf Res 28:1511-1526

> Dolan JR, Marrasé C (1995) Planktonic ciliate distribution relative to a deep chlorophyll maximum: Catalan Sea, N.W. Mediterranean, June 1993. Deep-Sea Res I 42: 1965-1987

> Dolan JR, Pérez MT (2000) Costs and benefits of mixotrophy: the case of marine oligotrichs. Freshw Biol 45:227-238 
Dolan JR, Vidussi F, Claustre H (1999) Planktonic ciliates in the Mediterranean Sea: longitudinal trends. Deep-Sea Res I 46:2025-2039

Dutz J, Peters J (2008) Importance and nutritional value of large ciliates for the reproduction of Acartia clausi during the post spring-bloom period in the North Sea. Aquat Microb Ecol 50:261-277

Fenchel T (1980) Relation between particle size selection and clearance in suspension-feeding ciliates. Limnol Oceanogr 25:733-738

Gasol JM (1994) A framework for the assessment of top-down vs bottom-up control of heterotrophic nanoflagellate abundance. Mar Ecol Prog Ser 113:291-300

- Gasol JM, Doval MD, Pinhassi J, Calderón-Paz JI, GuixaBoixareu N, Vaqué D, Predró-Alió C (1998) Diel variations in bacterial heterotrophic activity and growth in the northwestern Mediterranean Sea. Mar Ecol Prog Ser 164:107-124

Gustafson DE, Stoecker DK, Johnson MD, Van Heukelem WF, Sneider K (2000) Cryptophyte algae are robbed of their organelles by the marine ciliate Mesodinium rubrum. Nature 405:1049-1052

Iriarte A, Purdie DA (1994) Size distribution of chlorophyll a biomass and primary production in a temperate estuary (Southampton Water): the contribution of photosynthetic picoplankton. Mar Ecol Prog Ser 115:283-297

Johnson MD, Stoecker DK (2005) Role of feeding in growth and photophysiology of Myrionecta rubra. Aquat Microb Ecol 39:303-312

> Jonsson PR (1986) Particle size selection, feeding rates and growth dynamics of marine planktonic oligotrichous ciliates (Ciliophora: Oligotrichina). Mar Ecol Prog Ser 33: 265-277

Joux F, Servais P, Naudin JJ, Lebaron P, Oriol L, Courties C (2005) Distribution of picophytoplankton and bacterioplankton along a river plume gradient in the Mediterranean Sea. Vie Milieu 55:197-208

> Joux F, Jeffrey WH, Abboudi M, Pujo-Pay M, Oriol L, Neveux J, Naudin JJ (2009) Ultraviolet radiation in the Rhone lenses of low salinity and marine waters of the northwestern Mediterranean Sea: attenuation and effects on bacterial production and net community production. Photochem Photobiol 85:783-793

Karayanni H, Christaki U, Van Wambeke F, Denis M, Moutin $\mathrm{T}$ (2005) Influence of ciliated protozoa and heterotrophic nanoflagellates on the fate of primary production in the northeast Atlantic Ocean. J Geophys Res 110:C07S15. doi:10.1029/2004JC002602

Karayanni H, Christaki U, Van Wambeke F, Thyssen M, Denis M (2008) Heterotrophic nanoflagellate and ciliate bacterivorous activity and growth in the northeast Atlantic Ocean: a seasonal mesoscale study. Aquat Microb Ecol 51: 169-181

Kirchman DL (2001) Measuring bacterial biomass production and growth rates from leucine incorporation in natural aquatic environments. In: Paul JH (Ed.) Marine Microbiology. Academic Press, San Diego, CA, p. 227-237

Laval-Peuto M, Rassoulzadegan F (1988) Autofluorescence of marine planktonic Oligotrichina and other ciliates. Hydrobiologia 159:99-110

Lee S, Fuhrman JA (1987) Relationships between biovolume and biomass of naturally derived marine bacterioplankton. Appl Environ Microbiol 53:1298-1303

Lefèvre D, Minas HJ, Minas M, Robinson C, Le B, Williams PJ, Woodward EMS (1997) Review of gross community production, primary production, net community production and dark community respiration in the Gulf of Lions. Deep-Sea Res II 44:801-832
Maar M, Nielsen TG, Richardson K, Christaki U, Hansen OS, Zervoudaki S, Christou ED (2002) Spatial and temporal variability of food web structure during the spring bloom in the Skagerrak. Mar Ecol Prog Ser 239:11-29

Maeda M (1986) An illustrated guide to the species of the families Halteriidae and Strobilidiidae (Oligotrichida, Ciliophora), free swimming protozoa common in the aquatic environment. Bull Ocean Res Inst Univ Tokyo, Vol 21. University of Tokyo

Maeda M, Carey PG (1985) An illustrated guide to the species of the family Strombidiidae (Oligotrichida, Ciliophora), free swimming protozoa common in the aquatic environment. Bull Ocean Res Inst Univ Tokyo Vol. 19 University of Tokyo

McManus GB, Fuhrman JA (1986) Photosynthetic pigments in the ciliate Laboea strobila from Long Island Sound, USA. J Plankton Res 8:317-327

Modigh M (2001) Seasonal variations of photosynthetic ciliates at a Mediterranean coastal site. Aquat Microb Ecol 23:163-175

> Myung G, Yih W, Kim HS, Park JS, Cho BC (2006) Ingestion of bacterial cells by the marine photosynthetic ciliate Myrionecta rubra. Aquat Microb Ecol 44:175-180

Naudin JJ, Cauwet G, Chrétiennot-Dinet MJ, Deniaux B, Dévenon JL, Pauc H (1997) River discharges and wind influence upon particulate transfer at the land-ocean interaction: case study of the Rhone River plume. Estuar Coast Shelf Sci 45:303-316

> Naudin JJ, Cauwet G, Fajon C, Oriol L, Terzic S, Devenon JL, Broche P (2001) Effect of mixing on microbial communities in the Rhone River plume. J Mar Syst 28:203-227

> Neveux J, Lantoine F (1993) Spectrofluorometric assay of chlorophylls and phaeopigments using the least square approximation technique. Deep-Sea Res I 40:1747-1765

Palomera I (1992) Spawning of anchovy Engraulis enrasicolus, in the North-Western Mediterranean relative to hydrographic features in the region. Mar Ecol Prog Ser 79:37-44

> Pedrós-Alió C, Calderon-Paz JI, Guixa-Boixereu N, Estrada M, Gasol JM (1999) Bacterioplankton and phytoplankton biomass and production during summer stratification in the northwestern Mediterranean Sea. Deep-Sea Res I 46:985-1019

Porter KG, Feig YS (1980) The use of DAPI for identifying and counting aquatic microflora. Limnol Oceanogr 25: 943-948

> Pujo-Pay M, Conan P, Joux F, Oriol L, Naudin JJ, Cauwet G (2006) Impact of phytoplankton and bacterial production on nutrient and DOM uptake in the Rhone River plume (NW Mediterranean). Mar Ecol Prog Ser 315:43-54

Putt M, Stoecker DK (1989) An experimentally determined carbon: volume ratio for marine 'oligotrichous' ciliates from estuarine and coastal waters. Limnol Oceanogr 34: $1097-1103$

> Rublee PA, Gallegos CL (1989) Use of fluorescently labelled algae (FLA) to estimate microzooplankton grazing. Mar Ecol Prog Ser 51:221-227

Sabatés I, Salat J, Olivar PM (2001) Advection of continental water as an export mechanisms for anchovy, Engraulis encrasicolus, larvae. Sci Mar 65:77-88

Salat J (1996) Review of hydrographic environmental factors that may influence anchovy habitats in Northwestern Mediterranean. Sci Mar 60:21-32

> Sanders RW (1995) Seasonal distributions of the photosynthetic ciliates Laboea strobila and Myrionecta rubra (= Mesodinium rubrum) in an estuary of the Gulf of Maine. Aquat Microb Ecol 9:237-242 
Sherr BF, Sherr EB, Fallon RD (1987) Use of monodispersed, fluorescently labeled bacteria to estimate in situ protozoan bacterivory. Appl Environ Microbiol 53:958-965

Sime-Ngando T, Juniper K, Vézina A (1992) Ciliated protozoan communities over Cobb Seamount: increase in biomass and spatial patchiness. Mar Ecol Prog Ser 89:37-51

Šimek K, Hornák K, Masin M, Christaki U, Nedoma J, Weinbauer MG, Dolan JR (2003) Comparing the effects of resource enrichment and grazing on a bacterioplankton community of a meso-eutrophic reservoir. Aquat Microb Ecol 31:123-135

Stickney HL, Hood RR, Stoecker DK (2000) The impact of mixotrophy on planktonic marine ecosystems. Ecol Model 125:203-230

Stoecker DK, Michaels AE, Davis LH (1987) Large proportion of marine planktonic ciliates found to contain functional chloroplasts. Nature 326:790-792

Stoecker DK, Taniguchi A, Michaels AE (1989) Abundance of autotrophic, mixotrophic and heterotrophic planktonic ciliates in shelf and slope waters. Mar Ecol Prog Ser 50:241-254

Tréguer P, Le Corre P (1975) Manuel d'analyse des sels nutritifs dans l'eau de mer, utilisation de l'autoanalyzer II Technicon, 2nd edn. Laboratoire d'océanographie chimique, Université de Bretagne Occidentale, Brest

Tudela S, Palomera I (1997) Trophic ecology of the European anchovy Engraulis encrasicolus in the Catalan Sea (northwest Mediterranean). Mar Ecol Prog Ser 160:121-134

Submitted: April 27, 2009; Accepted: June 15, 2009
Vaqué D, Calderón-Paz JI, Guixa-Boixereu N, Pedrós-Alió C (2002) Spatial distribution of microbial biomass and activity (bacterivory and bacterial production) in the northern Weddell Sea during the austral summer (January 1994). Aquat Microb Ecol 29:107-121

> Vazquez-Dominguez E, Peters F, Gasol JM, Vaqué D (1999) Measuring the grazing losses of picoplankton: methodological improvements in the use of fluorescently labeled tracers combined with flow cytometry. Aquat Microb Ecol 20:119-128

Verity PG, Vernet M (1992) Microzooplankton grazing pigments and composition of plankton community during late spring in two Norwegian fjords. Sarsia 77:163-174

- Wieltschnig C, Wihlidal P, Ulbricht T, Kirschner AKT, Velimirov B (1999) Low control of bacterial production by heterotrophic nanoflagellates in a eutrophic backwater environment. Aquat Microb Ecol 17:77-89

Yih W, Kim HS, Jeong HJ, Myung G, Kim YG (2004) Ingestion of cryptophyte cells by the marine photosynthetic ciliate Mesodinium rubrum. Aquat Microb Ecol 36:165-170

Zahr JH (1984) Biostatistical analysis. Prentice Hall, Englewood Cliffs, NJ

> Zhang W, Xu K, Wan R, Zhang G and others (2002) Spatial distribution of ciliates, copepod nauplii and eggs, Engraulis japonicus post-larvae and microozoplankton herbivorous activity in the Yellow Sea, China. Aquat Microb Ecol 27:249-259

Proofs received from author(s): November 2, 2009 